\begin{tabular}{|c|l|}
\hline Title & $\begin{array}{l}\text { Dynamic photo-control of kinesin on a photoisomerizable monol ay er - hydrolysis rate of A TP and motility of } \\
\text { microtubules depending on the terminal group }\end{array}$ \\
\hline Author(s) & Rahim, M. K. A bdul; Kamei, Takashi; Tamaoki, Nobuy uki \\
\hline Citation & $\begin{array}{l}\text { Organic \& Biomolecular Chemistry, 10(16), 3321-3331 } \\
\text { https://doi.org/10.1039/c2ob07167c }\end{array}$ \\
\hline Issue Date & 2012-04 28 \\
\hline Doc URL & http://hdl.handle.net/2115/63001 \\
\hline Type & article (author version) \\
\hline File Information & revised MS RSC Article Template2.pdf \\
\hline
\end{tabular}

Instructions for use 


\title{
Dynamic photo-control of kinesin on a photoisomerizable monolayer- Hydrolysis rate of ATP and motility of microtubule depending on the terminal group
}

\author{
M. K. Abdul Rahim, ${ }^{a}{ }^{\text {Takashi Kamei }}{ }^{a}$ and Nobuyuki Tamaoki ${ }^{* a}$ \\ ${ }_{5}$ Received (in $\left.X X X, X X X\right)$ Xth $X X X X X X X X X 20 X X$, Accepted Xth $X X X X X X X X X 20 X X$ \\ DOI: $10.1039 / b 000000 x$
}

The reversibly and repeatedly altered gliding motility of microtubules driven by kinesin on the photoresponsive monolayer surface is studied. It was confirmed that an azobenzene monolayer surface needs to have free amino terminal groups for the successful dynamic control of the motility of

10 microtubule. The surface of azobenzene monolayer with terminal amino groups can dynamically control the ATP hydrolysis activity of kinesin which resulted in the change in motility of microtubule.

\section{Introduction}

The regulation of nano assembly devices and molecular machines using biomolecular motors as promising components is one of the 15 hot topic in nanotechnology and bioengineering. ${ }^{1-9}$ Kinesins are prominent microtubule associated motor proteins, which play a central role in both structural and biological functions of the cells. ${ }^{10-12}$ The fundamental role of kinesin is to actively distribute the intracellular materials like organelles, vesicles, chromosomes 20 along the microtubules ${ }^{13,14}$ and to drive the cell division process by converting the chemical energy of adenosine triphosphate (ATP) into mechanical energy with the positional movement towards the fast polymerizing plus ends of microtubules. ${ }^{15-17}$ Each kinesin molecule has two "heads", a $50 \mathrm{~nm}$ long semi${ }_{25}$ flexible coiled-coil region which binds to microtubules and hydrolyses ATP and a "tail", which is thought to bind to the cargo. ${ }^{18}$ Among the molecular motors, the kinesin-microtubule system is used widely for developing nanoscale biodevices, because the motility can be regenerated on a surface 30 comparatively easily. In the common in vitro construction of the kinesin-microtubule system, the kinesin are adsorbed onto a surface such as glass and microtubules are able to glide across the kinesin coated glass surface. ${ }^{14}$ The kinesin-microtubule system has other advantages such as, its small size, and the linear 35 movement of single kinesin along the microtubule compared to other molecular motor proteins. ${ }^{19,20}$

The ability to reversibly control the speed of microtubule gliding and the direction of movement on the surface of kinesin by external stimuli would greatly improve the sophistication of 40 nano devices. Several methodologies have been used for the artificial control of microtubule function which includes microlithographic tracks, ${ }^{21,22}$ electric and magnetic fields, ${ }^{23}$ antibody ${ }^{24}$ and so on. When considering the biodevices in the future, photochemical energy inputs offer advantages compared 45 to chemical energy inputs because (i) light does not generate waste products; (ii) it can be switched on/off easily and rapidly; (iii) photons, besides supplying the energy to the system, can also be useful to "read" the state of the system and thus to control and monitor the operation of the machine etc.. Higuchi et al. ${ }^{25}$ used 50 the caged ATP as photo-controlled switch, because their inactive caged states (OFF state of motility) can be converted to active uncaged states (ON state of motility) by UV light irradiation. Another group successfully used the photolysis of caged ATP to develop molecular shuttles on engineered kinesin tracks. ${ }^{26}$ On the 55 other hand Tatsu et al. demonstrated the switching of kinesin's activity from the ON state to the OFF state by the photolysis of caged peptide derived from the kinesin C-terminus domain working as an inhibitor. ${ }^{27}$ In that study, they successfully demonstrated an $80 \%$ reduction of the initial gliding velocity of 60 microtubules on the kinesin surface after the photochemical deprotection of the $o$-nitrobenzyl protecting group on the caged peptide. All these methods can either trigger the initiation of the movement or cessation of the microtubule motility. To design the more useful nanoscale biodevices, it is important that the system ${ }_{65}$ should provide ON and OFF switching of gliding motility at any desired time and at any desired position in space. To the best of our knowledge the light controlled reversible and repeated switching of microtubule motility was demonstrated only by our group. ${ }^{28}$

70 We reported the reversible and repeated regulation of the motility of microtubule by the photoisomerization of the underlying monolayer using two different wavelengths of light. ${ }^{28}$ For the fabrication of such photoresponsive monolayer, we employed a derivative of azobenzene; one of the most studied 75 photochromic compounds ${ }^{29-33}$ due to its strong photo-switching 
ARTICLE TYPE<smiles>CC(=O)Nc1ccc(NN(c2ccc(NC(C)=O)cc2)c2ccc(NC(C)=O)cc2)cc1</smiles><smiles>[R]Nc1ccc(N=Nc2ccc(N)cc2)cc1</smiles>
$7,8,9$

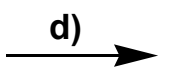<smiles>[R]Nc1ccc(N=Nc2ccc(NC(=O)NCCC[Si](OCC)(OCC)OCC)cc2)cc1</smiles><smiles>[Y7]C[R17]=[Y7]</smiles>

$8,1 c^{\prime}: \mathbf{R}=$<smiles>CC(=O)CCC(NC(C)=O)C(=O)OC(C)(C)C</smiles>

$9,1 d^{\prime}: R=$<smiles>CC(=O)CC(=O)O[Ge](C)(C)C</smiles>

Scheme 1 a) $\mathrm{NaBO}_{3}, \mathrm{H}_{3} \mathrm{BO}_{3}, \mathrm{HOAc}, \mathrm{HCl}, \mathrm{MeOH}, 60^{\circ} \mathrm{C}$. b) $\mathrm{NaOH}$. c) For 7, $\mathbf{1}^{\prime}=$ Boc-Arg-(Boc $)_{2}-\mathrm{OH}$, for $\mathbf{8}, \mathbf{1} \mathbf{c}^{\prime}=\mathrm{Boc}-\mathrm{Glu}-(\mathrm{OtBu})-\mathrm{OH}$ and for $\mathbf{9}, \mathbf{1} \mathbf{d}^{\prime}=$ Mono-tert-butyl malonate, DCC, $\mathrm{HOBt}$, DMF. d) $\mathrm{OCN}-\left(\mathrm{CH}_{2}\right)_{3}-\mathrm{Si}-(\mathrm{OEt})_{3}$, THF.

effect, reversibility and simplicity of incorporation, ${ }^{34}$ with a 5 triethoxy silane group which react with the glass surface to be anchored and a lysine group which can interact with motor proteins. Using this approach, we described the reversible and repeated control of the gliding velocity of microtubules driven by kinesin on the azobenzene monolayer (with a maximum of $15 \%$ 10 difference in velocity) upon irradiation with UV and visible light. ${ }^{35}$ In this paper we are reporting the generality of the system in the repeated regulation of fast and slow modes of microtubule gliding motility by devising a series of surface of azobenzene monolayers with various terminal groups. We also propose a

15 mechanism that accounts for the changes in the velocity of microtubule when the photoresponsive monolayer surface is isomerized between $E$ and $Z$ states upon irradiation of different wavelengths of light. We believe that the method developed here should be applicable in forthcoming nanoscale biodevices based 20 on the kinesin-microtubule system.

\section{Experimental}

\section{Materials}

Unless otherwise noted, all reagents including solvents were obtained from major commercial suppliers such as TCI, Sigma25 Aldrich and Wako used directly without further purification. DMF was routinely dried and/or distilled prior to use and stored over molecular sieves (4A). Column chromatography was performed with silica gel $(63-210 \mu \mathrm{m})$.

\section{General methods, instrumentation and measurements}

${ }_{30}^{1} \mathrm{H}$ NMR spectra were recorded at $400 \mathrm{MHz}$ using TMS as an internal standard. Matrix-Assisted Laser Desorption Ionization Time-Of-Flight Mass Spectrometry (MALDI-TOF MS) was performed on an applied Biosystems Voyager- DE pro instrument with positive-ion mode. Absorption spectra were recorded on an 35 Agilent 8453 spectrophotometer and also a Hitachi U-3100 absorption spectrophotometer. Photo-isomerization studies were 

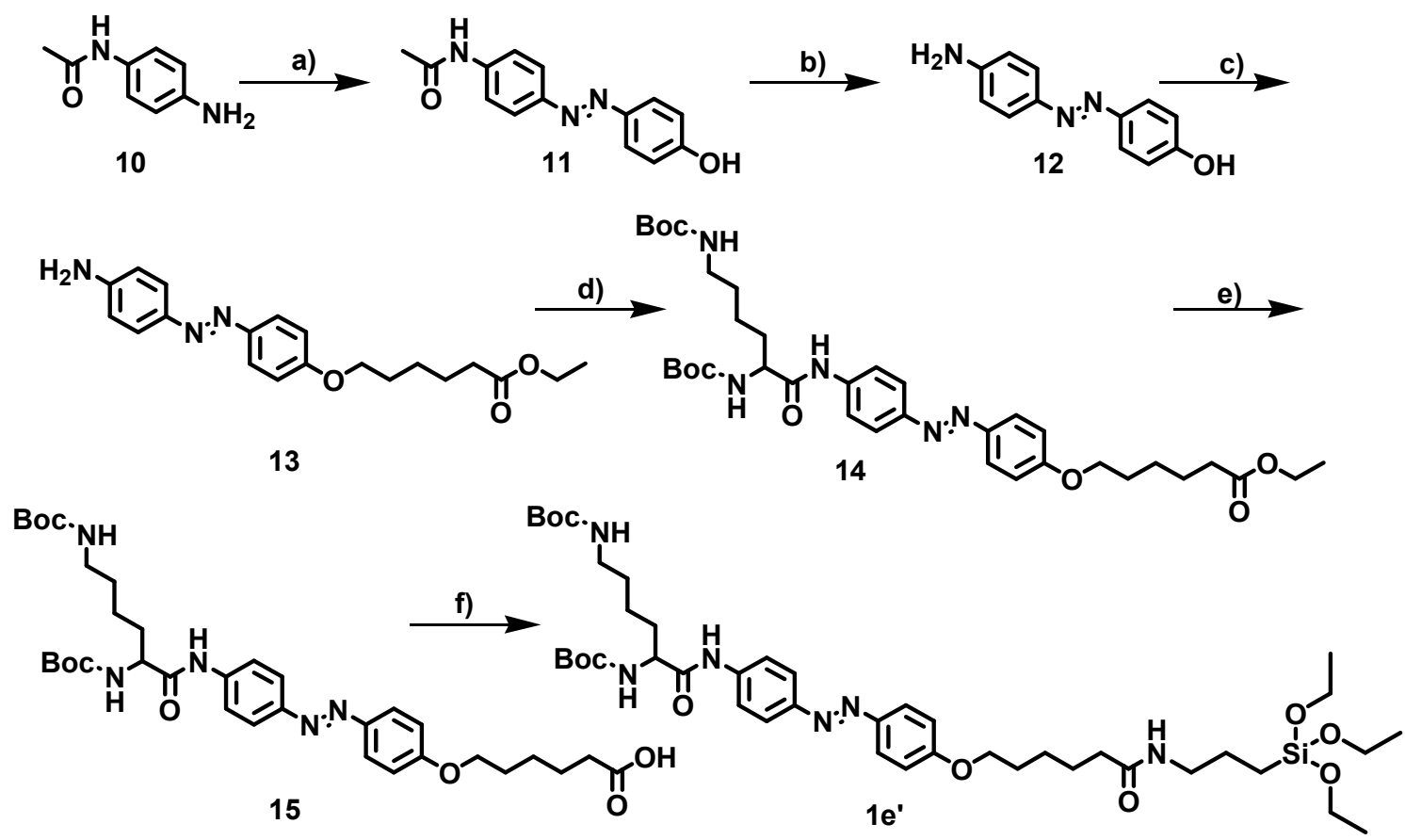

Scheme 2 a) $\mathrm{HCl}, \mathrm{H}_{2} \mathrm{O}, \mathrm{NaNO}_{2}, \mathrm{NaOH}, \mathrm{PhOH}, 0 \sim 2{ }^{\circ} \mathrm{C}$. b) $10 \% \mathrm{NaOH}$, Reflux 2h. c) $\mathrm{Br}-\left(\mathrm{CH}_{2}\right)_{5}-\mathrm{COOEt}, \mathrm{K}_{2} \mathrm{CO}_{3},\left(\mathrm{CH}_{3}\right)_{2} \mathrm{CO}, 50-60{ }^{\circ} \mathrm{C}$. d) Boc-Lys-(Boc)OH.DCHA, DCC, HOBt, DMF. e) Dioxane, $1 \mathrm{M}$ aq. KOH. f) OCN-(CH $)_{3}$-Si-(OEt $)_{3}$, THF.

conducted using a mercury-xenon lamp (Hamamatsu photonics ${ }_{5} \mathrm{~K} . \mathrm{K} 200 \mathrm{~W}$ ) after passage through appropriate filters (366 or 440 or $>500 \mathrm{~nm}$ ).

Microtubules motility assay were carried out using fluorescence microscope (Olympus BX50 or Nikon TEi) equipped with a high NA objective lens (100x, 1.30 NA for ${ }_{10}$ Olympus BX50 and 100x, 1.45 NA for Nikon TEi) and the fluorescence image was recorded with appropriate filters (Chroma) to remove the excitation light, back-illuminate electron-cooled CCD camera (EM9100-12, HAMAMATSU), and the image processing system AQUACOSMOS (HAMAMATSU). 15 Both were performed at room temperature $\left(22^{\circ} \mathrm{C}\right)$.

\section{Synthesis}

The synthetic route to compounds $\mathbf{1} \mathbf{b}^{\prime}-\mathbf{e}^{\prime}$ and $\mathbf{2 a}$ are illustrated in Scheme 1-3 and compound $\mathbf{2 b}$ was commercially purchased. Synthetic details of $\mathbf{1 a}^{\prime}$ were reported in our previous paper. 20 Detailed synthetic procedures for $\mathbf{1} \mathbf{b}^{\prime}-\mathbf{e}^{\prime}$ and $\mathbf{2 a}$ are described below. Compounds $\mathbf{4}$ and $\mathbf{5}$ were prepared according to the literature. $^{36}$

Compound 7. Hydroxybenzotriazole $(115 \mathrm{mg}, 0.848 \mathrm{mmol})$ and N,N'-Dicyclohexylcarbodiimide (175 mg, $0.848 \mathrm{mmol})$ were 25 added under an argon atmosphere to a solution of Boc-Arg$(\mathrm{Boc})_{2}-\mathrm{OH}(268 \mathrm{mg}, 0.565 \mathrm{mmol})$ in dry DMF $(5 \mathrm{~mL})$ at room temperature. After $1 \mathrm{~h}, 4,4^{\prime}$-diaminoazobenzene (5) (150 mg, $0.707 \mathrm{mmol}$ ) was added and the mixture was stirred at room temperature overnight. The mixture was then diluted with brine 30 and was extracted with ethyl acetate (EtOAc); the combined extracts were dried $\left(\mathrm{MgSO}_{4}\right)$ and the solvent was removed under reduced pressure. The residue was purified by column chromatography (eluent: dichloromethane (DCM) / EtOAc). Yield: $41 \%$. ${ }^{1} \mathrm{H}$ NMR (400 MHz, $\left.\mathrm{CDCl}_{3}\right): \delta=1.40(\mathrm{~s}, 9 \mathrm{H}), 1.51$ $35(\mathrm{~d}, \mathrm{~J}=4 \mathrm{~Hz}, 18 \mathrm{H}), 1.65-1.71(\mathrm{~m}, 2 \mathrm{H}), 1.82-1.95(\mathrm{~m}, 4 \mathrm{H}), 3.81$ (m, 1H), 4.07 (br, 2H), $4.55(\mathrm{~m}, 1 \mathrm{H}), 5.95(\mathrm{q}, \mathrm{J}=4 \mathrm{~Hz}, 1 \mathrm{H}), 6.72$ $(\mathrm{d}, \mathrm{J}=8 \mathrm{~Hz}, 2 \mathrm{H}), 7.61$ (d, J = 8 Hz, 2H), 7.77 (d, J = 8 Hz, 2H), $7.82(\mathrm{~d}, \mathrm{~J}=8 \mathrm{~Hz}, 2 \mathrm{H}), 9.19$ (br, 1H), 9.29 (br, 1H). MS (MALDI): Calculated for $\mathrm{C}_{33} \mathrm{H}_{48} \mathrm{~N}_{8} \mathrm{O}_{7}[\mathrm{M}+\mathrm{H}]^{+} \mathrm{m} / \mathrm{z}$ 669.36; 40 found $\mathrm{m} / \mathrm{z} 669.66$.

Compound 1 $\mathbf{b}^{\prime}$. Triethoxysilylpropyl isocyanate (62 $\mathrm{mg}, 0.251$ mmol) was added to a solution of $7(252 \mathrm{mg}, 0.377 \mathrm{mmol})$ in anhydrous tetrahydrofuran (THF) $(3 \mathrm{~mL})$. The mixture was refluxed under $\mathrm{N}_{2}$ atmosphere until the completion of the reaction. 45 The residue was washed with copious amounts of hexane and was then dried under vacuum. Yield: $71 \%$. ${ }^{1} \mathrm{H}$ NMR $(400 \mathrm{MHz}$, $\left.\mathrm{CDCl}_{3}\right): \delta=0.61(\mathrm{t}, \mathrm{J}=8 \mathrm{~Hz}, 2 \mathrm{H}), 1.17(\mathrm{t}, \mathrm{J}=8 \mathrm{~Hz}, 9 \mathrm{H}), 1.43$ (d, $\mathrm{J}=4 \mathrm{~Hz}, 18 \mathrm{H}), 1.52(\mathrm{~s}, 9 \mathrm{H}), 1.63(\mathrm{~m}, 2 \mathrm{H}), 1.77(\mathrm{~m}, 2 \mathrm{H}), 1.89(\mathrm{~m}$, 2H), 2.89 (q, J= $4 \mathrm{~Hz}, 2 \mathrm{H}), 3.23$ (q, J = 4 Hz, 2H), 3.79 (q, J= 8 $\left.{ }_{50} \mathrm{~Hz}, 6 \mathrm{H}\right), 3.96$ (m, 1H), 4.34 (br, 1H), 5.97 (q, J = 4 Hz, 1H), 6.33 (m, 2H), 7.67 (d, J = $8 \mathrm{~Hz}, 2 \mathrm{H}), 7.81(\mathrm{~d}, \mathrm{~J}=4 \mathrm{~Hz}, 2 \mathrm{H}), 7.83$ (d, J $=4 \mathrm{~Hz}, 2 \mathrm{H}), 7.85(\mathrm{~d}, \mathrm{~J}=4 \mathrm{~Hz}, 2 \mathrm{H}), 8.27(\mathrm{~s}$; urea $\mathrm{H}$ atom close to aryl, $1 \mathrm{H}), 9.26(\mathrm{br}, 1 \mathrm{H}) .{ }^{13} \mathrm{C}-\mathrm{NMR}\left(400 \mathrm{MHz}, \mathrm{CDCl}_{3}\right): \delta=$ $171.10,170.83,161.17,155.75,155.15,154.80,149.29,148.18$, $55141.84,141.70,124.07,123.55,120.14,119.34,82.96,82.33$, $80.00,58.52,55.63,48.47,42.70,28.43,28.09,24.99,23.47$, 22.99, 18.31, 7.66. MS (MALDI): Calculated for $\mathrm{C}_{3} \mathrm{H}_{69} \mathrm{~N}_{9} \mathrm{O}_{11} \mathrm{Si}$ 
$[\mathrm{M}+\mathrm{H}]^{+} \mathrm{m} / \mathrm{z}$ 917.48; found $\mathrm{m} / \mathrm{z} 917.43$.

Compound 8. Hydroxybenzotriazole (115 mg, $0.848 \mathrm{mmol}$ ) and N,N'-Dicyclohexylcarbodiimide (175 mg, $0.848 \mathrm{mmol})$ were added under an argon atmosphere to a solution of Boc-Glu$5(\mathrm{OtBu})-\mathrm{OH}(172 \mathrm{mg}, 0.565 \mathrm{mmol})$ in dry DMF $(5 \mathrm{~mL})$ at room temperature. 4,4'-diaminoazobenzene (5) $(150 \mathrm{mg}, 0.707 \mathrm{mmol})$ was added after $1 \mathrm{~h}$ and the mixture was stirred at room temperature overnight. The mixture was then diluted with brine and was extracted with ethyl acetate (EtOAc); the combined

10 extracts were dried $\left(\mathrm{MgSO}_{4}\right)$ and the solvent was removed under reduced pressure. The residue was purified by column chromatography (eluent: DCM / EtOAc). Yield: 43\%. ${ }^{1} \mathrm{H}$ NMR $\left(400 \mathrm{MHz}, \mathrm{CDCl}_{3}\right): \delta=1.45(\mathrm{~d}, \mathrm{~J}=8 \mathrm{~Hz}, 18 \mathrm{H}), 1.59-1.63(\mathrm{~m}$, 2H), 2.45-2.49 (t, J = 8 Hz, 2H), 4.09 (br, 2H), 4.24 (br, 1H), 5.4 $15(\mathrm{q}, \mathrm{J}=4 \mathrm{~Hz}, 1 \mathrm{H}), 6.71(\mathrm{~d}, \mathrm{~J}=8 \mathrm{~Hz}, 2 \mathrm{H}), 7.74(\mathrm{~d}, \mathrm{~J}=8 \mathrm{~Hz}, 2 \mathrm{H})$, $7.77(\mathrm{~d}, \mathrm{~J}=8 \mathrm{~Hz}, 2 \mathrm{H}), 7.83(\mathrm{~d}, \mathrm{~J}=8 \mathrm{~Hz}, 2 \mathrm{H}), 9.12(\mathrm{Br}, 1 \mathrm{H}) . \mathrm{MS}$ (MALDI): Calculated for $\mathrm{C}_{26} \mathrm{H}_{35} \mathrm{~N}_{5} \mathrm{O}_{5}[\mathrm{M}+\mathrm{H}]^{+} \mathrm{m} / \mathrm{z}$ 498.26; found $\mathrm{m} / \mathrm{z} 498.36$

Compound 1 $1 \mathbf{c}^{\prime}$. Triethoxysilylpropyl isocyanate $(76.6 \mathrm{mg}, 0.31$ $20 \mathrm{mmol})$ was added to a solution of $8(235 \mathrm{mg}, 0.465 \mathrm{mmol})$ in anhydrous tetrahydrofuran (THF) $(3 \mathrm{~mL})$. The mixture was refluxed under $\mathrm{N}_{2}$ atmosphere till the reaction was completed. The residue was washed with copious amounts of hexane and was then dried under vacuum. Yield: 79\%. ${ }^{1} \mathrm{H}$ NMR $(400 \mathrm{MHz}$, $\left.{ }_{25} \mathrm{CDCl}_{3}\right): \delta=0.65$ (t, J $\left.=8 \mathrm{~Hz}, 2 \mathrm{H}\right), 1.20(\mathrm{t}, \mathrm{J}=8 \mathrm{~Hz}, 9 \mathrm{H}), 1.46$ (d, $\mathrm{J}=8 \mathrm{~Hz}, 18 \mathrm{H}), 1.64(\mathrm{~m}, 2 \mathrm{H}), 2.23-2.33(\mathrm{~m}, 2 \mathrm{H}), 2.47-2.51(\mathrm{t}, \mathrm{J}$ $=8 \mathrm{~Hz}, 2 \mathrm{H}), 3.26(\mathrm{q}, \mathrm{J}=4 \mathrm{~Hz}, 2 \mathrm{H}), 3.79(\mathrm{q}, \mathrm{J}=6 \mathrm{~Hz}, 6 \mathrm{H}), 4.24$ (br, 1H), 5.39 (br, 1H), 5.42 (q, J = 4 Hz, 1H), 7.06 (br, 1H), 7.44 $(\mathrm{d}, \mathrm{J}=8 \mathrm{~Hz}, 2 \mathrm{H}), 7.73$ (d, J = 8 Hz, 2H), 7.79 (d, J = 8 Hz, 2H), $307.84(\mathrm{~d}, \mathrm{~J}=8 \mathrm{~Hz}, 2 \mathrm{H}), 9.24$ (s; urea $\mathrm{H}$ atom close to aryl, $1 \mathrm{H})$. ${ }^{13} \mathrm{C}-\mathrm{NMR}\left(400 \mathrm{MHz}, \mathrm{CDCl}_{3}\right.$ ): $\delta=171.21,155.31,149.63,149.02$ $142.22,141.68,124.00,123.70,119.94,119.42,82.94,80.71$, $58.53,53.20,42.68,34.25,31.00,28.35,27.96,25.80,23.48$, 22.65, 18.33, 7.62. MS (MALDI): Calculated for $\mathrm{C}_{36} \mathrm{H}_{56} \mathrm{~N}_{6} \mathrm{O}_{9} \mathrm{Si}$ $35[\mathrm{M}+\mathrm{H}]^{+} \mathrm{m} / \mathrm{z}$ 745.39; found $\mathrm{m} / \mathrm{z} 745.43$.

Compound 9. Hydroxybenzotriazole (191 mg, $1.4 \mathrm{mmol})$ and N,N'-Dicyclohexylcarbodiimide (292 mg, $1.4 \mathrm{mmol}$ ) were added under an argon atmosphere to a solution of mono-tert-butyl malonate $(151 \mathrm{mg}, 0.94 \mathrm{mmol})$ in dry DMF $(3 \mathrm{~mL})$ at room 40 temperature. After $1 \mathrm{~h}, 4,4^{\prime}$-diaminoazobenzene (5) $(250 \mathrm{mg}$, $1.18 \mathrm{mmol}$ ) was added and the mixture was stirred at room temperature overnight. The mixture was then diluted with brine and was extracted with ethyl acetate (EtOAc); the combined extracts were dried $\left(\mathrm{MgSO}_{4}\right)$ and the solvent was removed under 45 reduced pressure. The residue was purified through column chromatography (eluent: DCM / EtOAc). Yield: 46\%. ${ }^{1} \mathrm{H}$ NMR $\left(400 \mathrm{MHz}, \mathrm{CDCl}_{3}\right): \delta=1.45(\mathrm{~s}, 9 \mathrm{H}), 3.34(\mathrm{~s}, 2 \mathrm{H}), 3.97(\mathrm{br}, 2 \mathrm{H})$, $6.64(\mathrm{~d}, \mathrm{~J}=8 \mathrm{~Hz}, 2 \mathrm{H}), 7.62(\mathrm{~d}, \mathrm{~J}=8 \mathrm{~Hz}, 2 \mathrm{H}), 7.70(\mathrm{~d}, \mathrm{~J}=8 \mathrm{~Hz}$, 2H), $7.76(\mathrm{~d}, \mathrm{~J}=8 \mathrm{~Hz}, 2 \mathrm{H}), 9.50$ (br, 1H). MS (MALDI): ${ }_{50}$ Calculated for $\mathrm{C}_{19} \mathrm{H}_{22} \mathrm{~N}_{4} \mathrm{O}_{3}[\mathrm{M}+\mathrm{H}]^{+} \mathrm{m} / \mathrm{z}$ 355.17; found $\mathrm{m} / \mathrm{z}$ 355.08 .

Compound 1d'. Triethoxysilylpropyl isocyanate (104 mg, 0.42 $\mathrm{mmol})$ was added to a solution of $9(150 \mathrm{mg}, 0.42 \mathrm{mmol})$ in anhydrous tetrahydrofuran (THF) $(3 \mathrm{~mL})$. The mixture was

${ }_{55}$ refluxed under $\mathrm{N}_{2}$ atmosphere until the completion of the reaction. The residue was washed with copious amounts of hexane and was then dried under vacuum. Yield: $83 \%$. ${ }^{1} \mathrm{H}$ NMR $(400 \mathrm{MHz}$, $\left.\mathrm{CDCl}_{3}\right): \delta=0.64(\mathrm{t}, \mathrm{J}=8 \mathrm{~Hz}, 2 \mathrm{H}), 1.19(\mathrm{t}, \mathrm{J}=8 \mathrm{~Hz}, 9 \mathrm{H}), 1.52(\mathrm{~s}$,
9H), 1.60-1.69 (m, 2H), 3.23 (q, J = 4 Hz, 2H), 3.44 (s, 2 H), 3.78 60 (q, J = 6 Hz, 6H), $5.72(\mathrm{~m}, 2 \mathrm{H}), 7.40(\mathrm{~d}, \mathrm{~J}=8 \mathrm{~Hz}, 2 \mathrm{H}), 7.55$ (br, $1 \mathrm{H}), 7.63(\mathrm{~d}, \mathrm{~J}=4 \mathrm{~Hz}, 2 \mathrm{H}), 7.76(\mathrm{~d}, \mathrm{~J}=4 \mathrm{~Hz}, 2 \mathrm{H}), 7.80(\mathrm{~d}, \mathrm{~J}=4$ $\mathrm{Hz}, 2 \mathrm{H}), 9.64$ (s; urea $\mathrm{H}$ atom close to aryl, $1 \mathrm{H}) .{ }^{13} \mathrm{C}-\mathrm{NMR}(400$ $\left.\mathrm{MHz}, \mathrm{CDCl}_{3}\right): \delta=169.08,164.07,155.60,149.44,147.87$, $142.16,139.24,124.02,123.65,120.55,119.13,83.36,58.48$, ${ }_{65} 53.45,42.68,28.04,18.31,14.20,7.66$. MS (MALDI): Calculated for $\mathrm{C}_{29} \mathrm{H}_{43} \mathrm{~N}_{5} \mathrm{O}_{7} \mathrm{Si}[\mathrm{M}+\mathrm{H}]^{+} \mathrm{m} / \mathrm{z} 602.29$; found $\mathrm{m} / \mathrm{z} 602.39$

Compounds 11 and $\mathbf{1 2}$ were prepared according to the literature. ${ }^{37}$

Compound 13. 4-(4'-Hydroxyphenylazo) aniline (12) $(2.10 \mathrm{~g}$, $7010 \mathrm{mmol})$, 6-Bromo-hexanoic acid ethyl ester (3.4 g, $15.2 \mathrm{mmol})$ and potassium carbonate $(2.8 \mathrm{~g}, 38 \mathrm{mmol})$ was dissolved in acetone $(60 \mathrm{~mL})$ and the mixture was refluxed for 12 hours under argon atmosphere. The mixture was then diluted with brine and was extracted with ethyl acetate (EtOAc); the combined extracts 75 were dried $(\mathrm{MgSO} 4)$ and the solvent was removed under reduced pressure. The resulting mixture was submitted for silica column chromatography using a mixed solvent (DCM / EtOAc, 9:1) and 13 was obtained in $91 \%$ yield. ${ }^{1} \mathrm{H}$ NMR $\left(400 \mathrm{MHz}, \mathrm{CDCl}_{3}\right): \delta=$ $1.24(\mathrm{t}, \mathrm{J}=6 \mathrm{~Hz}, 3 \mathrm{H}), 1.50(\mathrm{~m}, 2 \mathrm{H}), 1.68(\mathrm{~m}, 2 \mathrm{H}), 1.80(\mathrm{~m}, 2 \mathrm{H})$, $802.32(\mathrm{t}, \mathrm{J}=8 \mathrm{~Hz}, 2 \mathrm{H}), 3.98(\mathrm{t}, \mathrm{J}=8 \mathrm{~Hz}, 2 \mathrm{H}), 4.02(\mathrm{br}, 2 \mathrm{H}), 4.10$ $(\mathrm{q}, \mathrm{J}=8 \mathrm{~Hz}, 2 \mathrm{H}), 6.72(\mathrm{~d}, \mathrm{~J}=8 \mathrm{~Hz}, 2 \mathrm{H}), 6.95(\mathrm{~d}, \mathrm{~J}=8 \mathrm{~Hz}, 2 \mathrm{H})$, $7.75(\mathrm{~d}, \mathrm{~J}=8 \mathrm{~Hz}, 2 \mathrm{H}), 7.81(\mathrm{~d}, \mathrm{~J}=8 \mathrm{~Hz}, 2 \mathrm{H})$. MS (MALDI): Calculated for $\mathrm{C}_{20} \mathrm{H}_{25} \mathrm{~N}_{3} \mathrm{O}_{3}[\mathrm{M}+\mathrm{H}]^{+} \mathrm{m} / \mathrm{z}$ 356.20; found $\mathrm{m} / \mathrm{z}$ 356.23 .

${ }_{85}$ Compound 14. To a DMF $(10 \mathrm{~mL})$ solution of Boc-Lys(Boc).DCHA (520 mg, $1.4 \mathrm{mmol})$ at $0{ }^{\circ} \mathrm{C}$, HOBt (200 mg, 1.48 $\mathrm{mmol}), \mathrm{EDC}(284 \mathrm{mg}, 1.48 \mathrm{mmol})$ and $\mathrm{Et}_{3} \mathrm{~N}(0.196 \mu \mathrm{L}, 1.4$ mmol) were added under argon atmosphere. After keeping for 15 minutes at $0{ }^{\circ} \mathrm{C}$ and 30 minutes at room temperature, the 90 compound 13 (510 $\mathrm{mg}, 1.44 \mathrm{mmol}$ ) was added and the mixture was stirred overnight at room temperature. The mixture was diluted with brine and was extracted with ethyl acetate, dried over $\mathrm{MgSO}_{4}$ and the solvent was removed under reduced pressure. The residue was purified using column chromatography (DCM / 95 AcOEt mixture as eluents (8:2)) and $\mathbf{1 4}$ were obtained as yellow powder in $48 \%$ yield. ${ }^{1} \mathrm{H}$ NMR $\left(400 \mathrm{MHz}, \mathrm{CDCl}_{3}\right): \delta=1.19(\mathrm{~m}$, $2 \mathrm{H}), 1.24(\mathrm{t}, \mathrm{J}=6 \mathrm{~Hz}, 3 \mathrm{H}), 1.31(\mathrm{~m}, 2 \mathrm{H}), 1.43(\mathrm{~d}, \mathrm{~J}=8 \mathrm{~Hz}, 18 \mathrm{H})$, $1.52(\mathrm{~m}, 2 \mathrm{H}), 1.70(\mathrm{~m}, 2 \mathrm{H}), 1.80(\mathrm{~m}, 2 \mathrm{H}), 1.88(\mathrm{~m}, 2 \mathrm{H}), 2.32(\mathrm{t}, \mathrm{J}$ $=6 \mathrm{~Hz}, 2 \mathrm{H}), 3.15(\mathrm{~m}, 2 \mathrm{H}), 3.79(\mathrm{q}, \mathrm{J}=8 \mathrm{~Hz}, 2 \mathrm{H}), 4.02(\mathrm{t}, \mathrm{J}=6$ $100 \mathrm{~Hz}, 2 \mathrm{H}), 4.17(\mathrm{br}, 1 \mathrm{H}), 4.61(\mathrm{~m}, 1 \mathrm{H}), 5.21(\mathrm{br}, 1 \mathrm{H}), 6.96(\mathrm{~d}, \mathrm{~J}=$ $12 \mathrm{~Hz}, 2 \mathrm{H}), 7.68(\mathrm{~d}, \mathrm{~J}=8 \mathrm{~Hz}, 2 \mathrm{H}), 7.85(\mathrm{~d}, \mathrm{~J}=4 \mathrm{~Hz}, 2 \mathrm{H}), 7.87(\mathrm{~d}$, $\mathrm{J}=4 \mathrm{~Hz}, 2 \mathrm{H}$ ), 8.64 (br, 1H). MS (MALDI): Calculated for $\mathrm{C}_{36} \mathrm{H}_{53} \mathrm{~N}_{5} \mathrm{O}_{8}[\mathrm{M}+\mathrm{H}]^{+} \mathrm{m} / \mathrm{z}$ 684.40; found $\mathrm{m} / \mathrm{z} 684.47$.

Compound 15. To a solution of $14(200 \mathrm{mg}, 0.29 \mathrm{mmol})$ in 105 dioxane $(6.0 \mathrm{~mL}), 1 \mathrm{M} \mathrm{KOH}$ aqu.solution $(3 \mathrm{~mL})$ was added. After stirring for $2 \mathrm{~h}$ at room temperature the mixture was neutralized with $2 \mathrm{~N} \mathrm{NH}_{4}^{+} \mathrm{Cl}^{-}$, extracted with AcOEt and was dried over $\mathrm{MgSO}_{4}$. The residue was purified by column chromatography (AcOEt) and $\mathbf{1 5}$ was obtained in $47 \%$ yield. ${ }^{1} \mathrm{H}$ $10 \mathrm{NMR}\left(400 \mathrm{MHz}, \mathrm{CDCl}_{3}\right): \delta=1.24(\mathrm{~m}, 2 \mathrm{H}), 1.45(\mathrm{~d}, \mathrm{~J}=4 \mathrm{~Hz}$, $18 \mathrm{H}), 1.50(\mathrm{~m}, 2 \mathrm{H}), 1.68(\mathrm{~m}, 2 \mathrm{H}), 1.81(\mathrm{~m}, 2 \mathrm{H}), 1.86(\mathrm{~m}, 2 \mathrm{H})$, $2.03(\mathrm{~m}, 2 \mathrm{H}), 2.33(\mathrm{t}, \mathrm{J}=8 \mathrm{~Hz}, 2 \mathrm{H}), 3.09(\mathrm{~m}, 2 \mathrm{H}), 4.02(\mathrm{t}, \mathrm{J}=6$ $\mathrm{Hz}, 2 \mathrm{H}), 4.05(\mathrm{br}, 1 \mathrm{H}), 4.65(\mathrm{~m}, 1 \mathrm{H}), 5.21(\mathrm{br}, 1 \mathrm{H}), 6.96(\mathrm{~d}, J=$ $12 \mathrm{~Hz}, 2 \mathrm{H}), 7.68(\mathrm{~d}, J=8 \mathrm{~Hz}, 2 \mathrm{H}), 7.85(\mathrm{~d}, J=4 \mathrm{~Hz}, 2 \mathrm{H}), 7.87$ (d, ${ }_{115} J=4 \mathrm{~Hz}, 2 \mathrm{H}$ ), 8.65 (br, 1H). MS (MALDI): Calculated for $\mathrm{C}_{34} \mathrm{H}_{49} \mathrm{~N}_{5} \mathrm{O}_{8}[\mathrm{M}+\mathrm{H}]^{+} m / z$ 656.34; found $m / z 656.36$. 


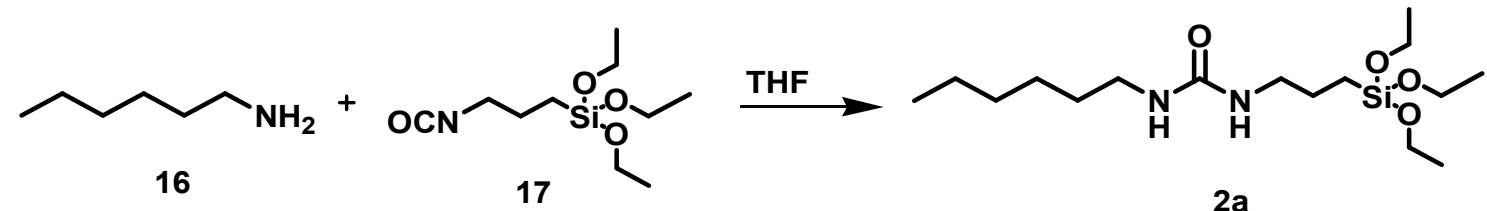

Scheme 3 Synthetic scheme of compound $\mathbf{2 a}$

Compound 1e'. The mixture solution of $100 \mathrm{mg}(0.15 \mathrm{mmol})$ of $15,67 \mathrm{mg}(0.31 \mathrm{mmol})$ of (3-aminopropyl) triethoxy silane and $567 \mathrm{mg}(0.31 \mathrm{mmol})$ of dicyclohexylcarbodiimide in DCM (12 $\mathrm{mL}$ ) was stirred for $2 \mathrm{~h}$ under ice cooling. The precipitated dicyclohexylurea was removed by filtration. The filtrate was evaporated under reduced pressure, washed with copious amounts of hexane and was then dried under vacuum affording the product 10 as orange solid. The crude residue $1 \mathbf{e}^{\prime}$ was used without any further purification. ${ }^{1} \mathrm{H} \mathrm{NMR}\left(400 \mathrm{MHz}, \mathrm{CDCl}_{3}\right): \delta=0.86(\mathrm{t}, J=$ $4 \mathrm{~Hz}, 2 \mathrm{H}), 1.24(\mathrm{t}, J=6 \mathrm{~Hz}, 9 \mathrm{H}), 1.45(\mathrm{~d}, J=4 \mathrm{~Hz}, 18 \mathrm{H}), 1.51-$ $1.61(\mathrm{~m}, 10 \mathrm{H}), 1.68-17.76(\mathrm{~m}, 2 \mathrm{H}), 1.80-1.88(\mathrm{~m}, 2 \mathrm{H}), 1.95(\mathrm{t}, J$ $=8 \mathrm{~Hz}, 2 \mathrm{H}), 2.33(\mathrm{t}, J=6 \mathrm{~Hz}, 2 \mathrm{H}), 3.09(\mathrm{~m}, 2 \mathrm{H}), 3.79(\mathrm{t}, J=4$ $15 \mathrm{~Hz}, 1 \mathrm{H}), 4.02$ (t, $J=6 \mathrm{~Hz}, 2 \mathrm{H}), 4.11$ (q, $J=4 \mathrm{~Hz}, 6 \mathrm{H}), 4.19$ (br, $1 \mathrm{H}), 4.64(\mathrm{~m}, 1 \mathrm{H}), 5.21(\mathrm{br}, 1 \mathrm{H}), 6.96(\mathrm{~d}, J=4 \mathrm{~Hz}, 2 \mathrm{H}), 7.67(\mathrm{~d}$, $J=12 \mathrm{~Hz}, 2 \mathrm{H}), 7.85(\mathrm{~d}, J=4 \mathrm{~Hz}, 2 \mathrm{H}), 7.87$ (d, $J=4 \mathrm{~Hz}, 2 \mathrm{H})$, 8.65 (br, $1 \mathrm{H})$. Yield was $86 \%$. ${ }^{13} \mathrm{C}-\mathrm{NMR}\left(400 \mathrm{MHz}, \mathrm{CDCl}_{3}\right): \delta=$ $172.35,169.57,160.27,155.22,152.92,148.04,145.87,138.77$, $20123.49,122.47,118.71,113.58,79.47,78.25,66.88,58.81,52.46$, $48.60,47.96,34.52,32.83,31.64,29.88,27.93,27.37,27.25$, 25.25, 21.52, 18.35, 17.21, 8.59. MS (MALDI): Calculated for $\mathrm{C}_{34} \mathrm{H}_{49} \mathrm{~N}_{5} \mathrm{O}_{8}[\mathrm{M}+\mathrm{H}]^{+} m / z$ 859.49; found $m / z$ 859.62.

Compound 2a. To a solution of hexylamine (16) (1.53 g, 15.18 $25 \mathrm{mmol})$ in THF $(6 \mathrm{~mL})$ was added to triethoxysilylpropyl isocyanate (17) $(2.5 \mathrm{~g}, 10.1 \mathrm{mmol})$ and was refluxed for 36 hour at argon atmosphere. After the completion of reaction, the residue was washed with copious amount of hexane and was dried under vacuum. Yield: $78 \%$. ${ }^{1} \mathrm{H} \mathrm{NMR}\left(400 \mathrm{MHz}, \mathrm{CDCl}_{3}\right.$ ): $\delta=0.52$ (t, $J$ $30=12 \mathrm{~Hz}, 2 \mathrm{H}), 0.79(\mathrm{t}, J=4 \mathrm{~Hz}, 3 \mathrm{H}), 1.11(\mathrm{t}, J=8 \mathrm{~Hz}, 9 \mathrm{H}), 1.20$ (m, 4H), $1.37(\mathrm{~m}, 2 \mathrm{H}), 1.50(\mathrm{~m}, 2 \mathrm{H}), 1.78(\mathrm{~m}, 2 \mathrm{H}), 3.05(\mathrm{~m}, 4 \mathrm{H})$, $3.71(\mathrm{q}, J=6 \mathrm{~Hz}, 6 \mathrm{H}), 5.23(\mathrm{~m}, 2 \mathrm{H})$. MS (MALDI): Calculated for $\mathrm{C}_{16} \mathrm{H}_{36} \mathrm{~N}_{2} \mathrm{O}_{4} \mathrm{Si}[\mathrm{M}+\mathrm{H}]^{+} \mathrm{m} / z$ 349.24; found $\mathrm{m} / z$ 349.36.

\section{Preparation of monolayer}

${ }_{35}$ Preparation of monolayer was done by a modification of the methods described elsewhere ${ }^{38}$ through the formation of siloxane linkages between 1a-d or 2a and the substrate. Glass or quartz plates were purified ultrasonically in acetone, in concentrated nitric acid and aqueous solution of saturated sodium bicarbonate 40 in sequence. Each ultra-sonication was carried out for $10 \mathrm{~min}$ and followed by washing with Milli-Q water. After drying at $120{ }^{\circ} \mathrm{C}$ for 30 minutes, the plates were dipped in a mixed THF solution containing compound $\mathbf{1} \mathbf{a}^{\prime}-\mathbf{e}^{\prime}$ along with compound $\mathbf{2 a}$ or $\mathbf{2 b}$ (total concentration: $2 \mathrm{mM}$ ) at room temperature for 30 minutes. The 45 modified plates were dried at $120{ }^{\circ} \mathrm{C}$ for 30 minutes and washed ultrasonically in THF for 10 minutes and dried again at $120^{\circ} \mathrm{C}$ for 30 minutes. The tert-Boc protecting groups of $\mathbf{1 a}^{\prime}-\mathbf{e}^{\prime}$ were removed by dipping the monolayer in a $30 \%$ trifluoroacetic acid (TFA) in DCM solution ${ }^{39}$ which yielded the target compounds ${ }_{50}$ 1a-e. The quantitative removal of the tert-Boc protecting group was verified by the measurements of contact angle before and after deprotection.

\section{Optical measurements and photoisomerization}

For photo-switching the azobenzene $\mathbf{1 a}^{\mathbf{\prime}}-\mathbf{d}^{\prime}$, samples (in 55 acetonitrile, $22{ }^{\circ} \mathrm{C}$ ) were irradiated at $366 \mathrm{~nm}$ (trans to cis) and $>500 \mathrm{~nm}$ (cis to trans), and $1 \mathbf{e}^{\prime}$ sample (in DCM, $22{ }^{\circ} \mathrm{C}$ ) were irradiated with $366 \mathrm{~nm}$ (trans to cis) and $440 \mathrm{~nm}$ (cis to trans) respectively, using a mercury-xenon lamp (Hamamatsu photonics K.K 200W) and band-pass filters (366, >500 and $440 \mathrm{~nm}$ ). ${ }_{60}$ Thermal relaxation of the cis to the trans isomer was monitored with the same spectrophotometer under dark condition. The absorption spectra of mixed monolayer of 1a-e incorporated on a quartz plate were recorded with same method and time as in solution, before and after photoirradiation using appropriate ${ }_{65}$ band-pass filters $(366,>500$ and $440 \mathrm{~nm})$ on a Hitachi U-3100 absorption spectrophotometer.

\section{Contact angle measurements}

The sample consisting of the monolayer was placed on a flat surface and water which is used as fluid was dropped on the 70 sample using syringe. The image of the sample was obtained by adjusting the light and focus of the camera. To confirm the deprotection of tert-Boc group, images were taken before and after deprotection and to know the reversible changes in surface property upon photoirradiation; images were taken before and 75 after $366 \mathrm{~nm}$ wavelength light irradiation.

\section{Proteins preparations}

Tubulins were purified from porcine brains through two cycles of polymerization-depolymeraization processes in the presence of a high-molarity PIPES buffer. ${ }^{40}$ MTs were polymerized using the ${ }_{80}$ purified tubulins and labelled with tetramethylrhodamine succinimidyl ester. Kinesin utilized in this research was a recombinant kinesin consist of 573 amino acid residues from Nterminus of a conventional human kinesin. This recombinant kinesin fused with His-tag in the N-terminus (plasmid; pET30b) 85 was expressed in Escherichia coli Rosetta (DE3) pLysS and purified by the general method utilizing Ni-NTA-agarose.

\section{Flow cells}


<smiles>[R]Nc1ccc(N=Nc2ccc(NC(=O)NCCC[Si](OCC)(OCC)OCC)cc2)cc1</smiles><smiles>[17CH]=CC(=O)C(N)CCCCN</smiles><smiles>N=C(N)NCCCC(N)C(=O)C=[Ru]</smiles><smiles>CCO[Si](CCCNC(=O)CCCCCOc1ccc(N=Nc2ccc(NC(=O)C(N)CCCCN)cc2)cc1)(OCC)OCC</smiles>

$2 a=$<smiles>CCCCCCNC(=O)NCCC[Si](OCC)(OCC)OCC</smiles><smiles>CCO[Si](CC)(CCCCCCCCCCCCCCCCC[PH3+])OCC</smiles>

Chart 1 Chemical structure of photoresponsive azobenzene silane compound (1a-e) along with alkyl silane chain (2a and 2b)
The flow cells were prepared by placing two strips of doublestick tape on a glass slide ca. $6-9 \mathrm{~mm}$ apart and covered with an $518 \times 18$ or $22 \times 22 \mathrm{~mm}$ cover slip consisting of monolayer. The inner volume of the obtained flow cell was ca. 10-12 $\mu \mathrm{L}$. Solutions were pipetted on one side and sucked out on the other side by capillary action using Whatman filter paper or a Kim wipe as shown somewhere. ${ }^{41,42}$

\section{Motility assays}

For these experiments, a simple protocol by using the standard capillary flow technique reported elsewhere for kinesin motility assay with polarity marked taxol MTs ${ }^{11}$ was employed. For all experiment the starting buffer was BRB80 (80 mM PIPES, $2 \mathrm{mM}$
${ }_{15} \mathrm{MgCl}_{2}, 1 \mathrm{mM}$ EGTA, pH 6.95 with $\left.\mathrm{KOH}\right)$. The azobenzene embedded flow cells were sequentially filled with a standard kinesin solution $(0.3069 \mathrm{mg} / \mathrm{mL}$, which is just sufficient for the movement of MTs) and kept in moist condition for five minutes. Unbound kinesins were washed out with a solution containing 20 $20 \mu \mathrm{l}$ of BRB80 assay buffer $+1 \mathrm{mM}$ DTT $+1 \mathrm{mM} \mathrm{MgATP}+10$ $\mu \mathrm{M}$ taxol. And then a motility buffer consisting of BRB80 and microtubules labelled by tetramethylrhodamine succinimidyl ester were stabilized with taxol $(5-10 \mu \mathrm{m}$ in length). After keeping this for five minutes, the unbound MTs were washed out 25 by the assay buffer containing taxol with an added oxygen scavenger system (2-mercaptoethanol: $0.14 \mathrm{M}$, glucose $20 \mathrm{mM}$, catalase: $20 \mu \mathrm{g} / \mathrm{ml}$, glucose oxidase: $100 \mu \mathrm{g} / \mathrm{ml})$. The flow cells 
(1)

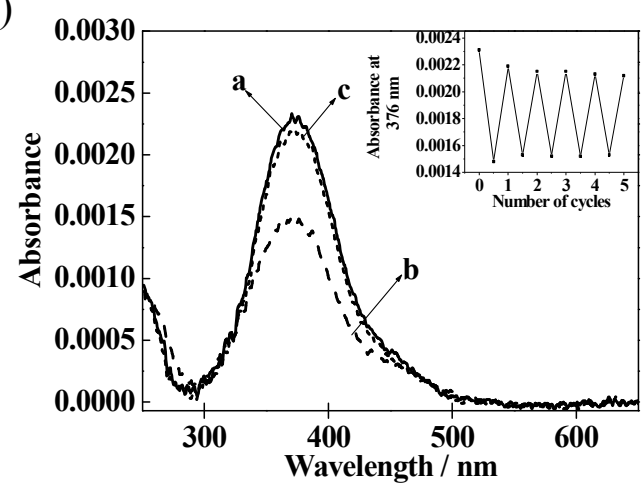

(3)

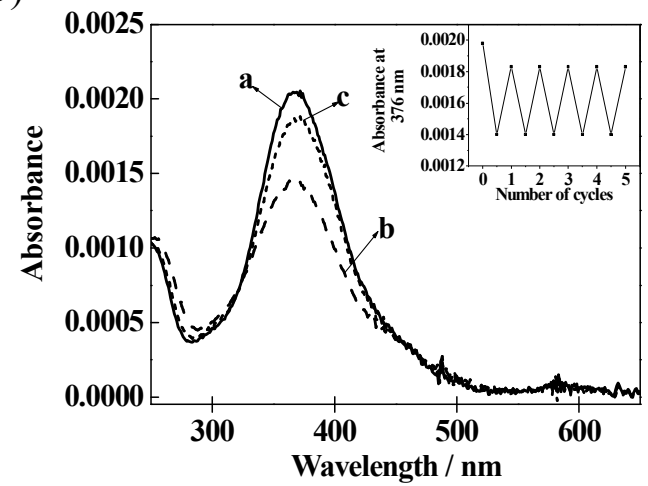

(5)

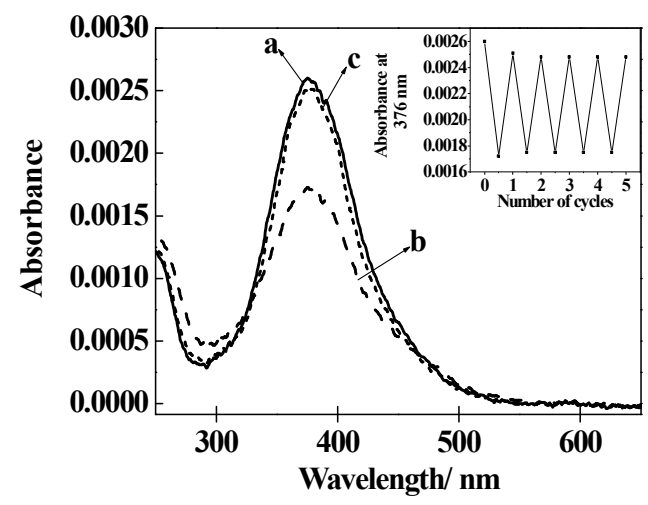

(7)

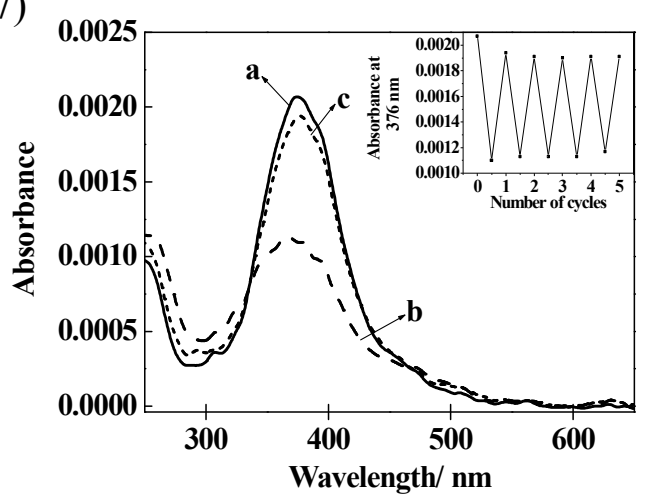

(2)

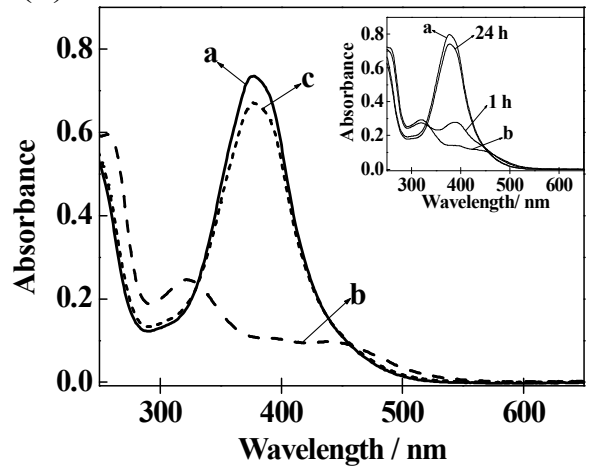

(4)

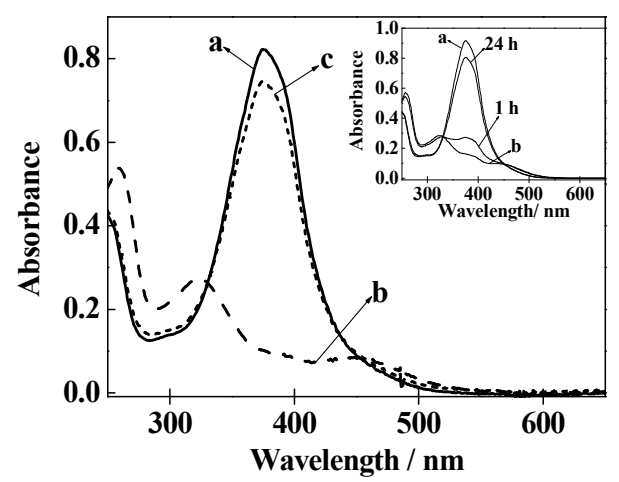

(6)

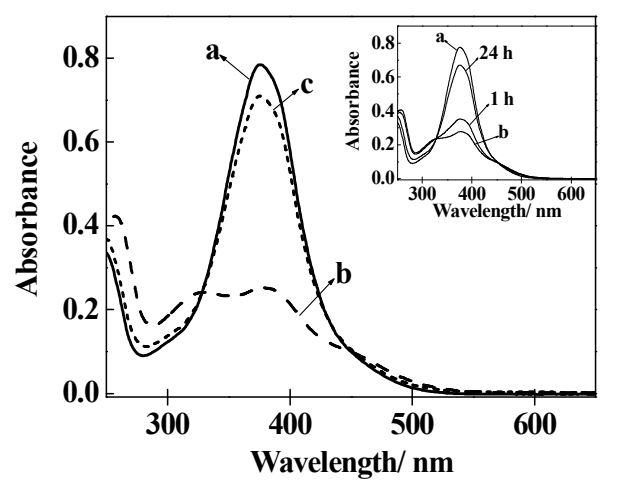

(8)

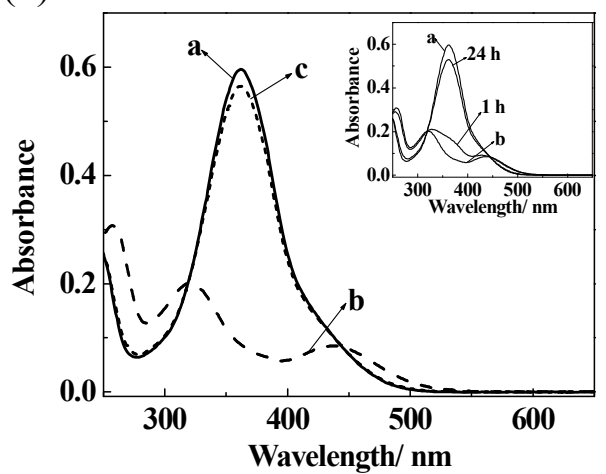

Fig. 1 Absorption spectral changes of $10 \%$ of $\mathbf{1 b}$-e and $90 \%$ of $\mathbf{2 a}$ or $\mathbf{2 b}$ in quartz surface after deprotection of tert-Boc group [left (1), (3), (5), (7)] and that of $\mathbf{1} \mathbf{b}^{\prime}-\mathbf{d}^{\prime}$ in acetonitrile and $\mathbf{1} \mathbf{e}^{\prime}$ in DCM before deprotection of tert-Boc group [right (2), (4), (6), (8)]. (a) Before irradiation. (b) photostationary state 
(PSS) at $366 \mathrm{~nm}$. (c) PSS at visible light. The inset in the left side shows the absorbance changes at $376 \mathrm{~nm}$ after alternating irradiation at $366 \mathrm{~nm}$ and visible light over five cycles. Inset in the right side shows the thermal-back relaxation at $22{ }^{\circ} \mathrm{C}$ in the dark with the indicated time as well as spectra of pure $E$-isomer (a) and photostationary state under $366 \mathrm{~nm}$ light irradiation (b). Smoothing was done to the original spectra of the monolayer to remove spike like noise coming from the instrument.

5 were sealed with immersion oil to prevent evaporation and were transferred to the fluorescence microscope. The translocation of MTs were monitored and recorded after UV and visible light irradiation.

\section{ATPase assays}

10 In the presence of azobenzene monolayer and microtubules, the kinesin ATPase activity was measured via a simple and sensitive colorimetric assay based on the determination of released inorganic phosphate ion by an improved malachite green procedure. $^{43,44}$ In short, at fixed time intervals, aliquots were 15 removed from the motility assay system and quickly mixed with equal volume of ice-chilled perchloric acid (PCA) and malachite green reagent. The mixture was kept at $25{ }^{\circ} \mathrm{C}$ for 40 minutes and then the absorbance was measured at $630 \mathrm{~nm}$ with a Hitachi U3100 absorption spectrophotometer and concentration of 20 inorganic phosphate $(\mathrm{Pi})$ was determined. Then the same flow cell was irradiated with $366 \mathrm{~nm}$ light until the sample reached its photostationary state (PSS). The aliquots at fixed time intervals were removed from the motility assay system and mixed with equal volumes of ice-chilled PCA and malachite green reagent 25 and the same procedure was repeated. In order to know the reproducibility, the above procedure was repeated by irradiating the flow cells with visible light.

\section{Results and Discussion}

The dynamic control of the motility of microtubule driven by 30 kinesin, upon photo-isomerization of azobenzene monolayer was studied with alkyl silane compounds shown in Chart 1, namely, 3-(triethoxysilyl)propyl urea attached to azobenzene moiety with one lysine (1a), arginine (1b), glutamic acid (1c) or malonic acid residue (1d) at the end and a 3-(triethoxysilyl)propyl 6-hydroxy35 hexanoic amide attached to azobenzene moiety with lysine residue (1e) at the end. One of the issues in the synthesis of silane functionalized azobenzene was the difficulty in purifying the final product. Without the purification of the final products, on the basis of HPLC, we estimated $93 \%$ purity with unreacted 40 azobenzene starting material as impurity. Since the azobenzene starting material is not reactive towards the glass surface, we did not consider its presence as a problem for monolayer formation.

One of the important parameters for fabrication of dynamic monolayer surfaces is reversibility of switching. Pace et al. ${ }^{45}$ 45 already reported that steric constraints of tightly packed matrixes can restrict conformational changes, thus hindering isomerization in azobenzene. In order to avoid such hindrance, we prepared a mixed monolayer which can reduce the steric constraints. For compound 1a-d, we used $90 \%$ of non-photo isomerizable 50 compound 2a for preparing mixed monolayer which forms hydrogen bonding with each other, and for $1 \mathbf{e}$ we used $90 \%$ of $\mathbf{2 b}$ The removal of tert-Boc groups on the surface upon TFA treatment is confirmed by the change in the contact angle. The contact angle of monolayer, before release of tert-Boc group of ${ }_{55} \mathbf{1 b}^{\prime}$ was $74^{\circ}$ and after $4 \mathrm{~h}$ treatment with TFA, it is reduced to $66^{\circ}$ The other compounds also show the similar trend of water contact angle, which is summarized in the table (ESI table S1).

Fig. 1 shows the absorption spectra of azobenzene monolayer before and after photoirradiation on a quartz plate and also in 60 solution. The details of absorption spectra of $\mathbf{1 a}$ on quartz surface and in solution are described in our previous report. ${ }^{28}$ The absorption spectra of monolayer of $\mathbf{1 b}$ on quartz surface before the irradiation of $366 \mathrm{~nm}$ light shows a strong absorption band at $375 \mathrm{~nm}$ which corresponds to the $\pi-\pi^{*}$ transition of the ${ }_{65}$ substituted $E$-azobenzene. The intensity of the band is decreased upon $366 \mathrm{~nm}$ light irradiation and the $\mathrm{n}-\pi^{*}$ transition band around $500 \mathrm{~nm}$ was increased. The film reaches its photo stationary state within 40 seconds. On further irradiation with $>500 \mathrm{~nm}$ wavelength light led to the recovery of the $\pi-\pi^{*}$ transition; the 70 system reached another PSS within 240 seconds. These spectral changes can be repeated for many cycles (inset). The similar behaviour of absorption spectra was observed for $\mathbf{1} \mathbf{b}^{\prime}$ maintaining tert-Boc groups in $\mathrm{CH}_{3} \mathrm{CN}$ solution which is the typical phenomenon shown between the $E$ and $Z$ isomerization states of 75 azobenzene derivatives. ${ }^{46,47}$ The thermal stability of $Z$ isomer of $\mathbf{1} \mathbf{b}^{\prime}$ in $\mathrm{CH}_{3} \mathrm{CN}$ at $22{ }^{\circ} \mathrm{C}$, (the temperature at which microtubule motility assay has been done) was also confirmed under the dark condition (inset). Only very small percentage of $Z$ isomer of $\mathbf{1} \mathbf{b}^{\prime}$ converts into $E$ isomer after $1 \mathrm{~h}$ and for a complete recovery, it 80 takes more than $24 \mathrm{~h}$ (Fig. 1, right). Therefore, the contribution of thermal-back reaction can be excluded from our few hour experiments of the motility assay. Similar photoisomerization changes and thermal stabilities are observed for $10 \% \mathbf{1 c}$ or $\mathbf{1 d}$ along with $90 \% \mathbf{2 a}$ and $\mathbf{1 e}$ with $\mathbf{2 b}$ on quartz surface and also in 85 corresponding solution of $\mathbf{1}^{\mathbf{\prime}} \mathbf{-}-\mathbf{e}^{\mathbf{\prime}}$ upon alternate irradiation of corresponding UV and visible light. After $366 \mathrm{~nm}$ light irradiation, the film reaches its PSS within 40 seconds for 1c, 1d and 1e. On further irradiation with corresponding visible light, the film reaches another PSS within 300 seconds for 1c and 1d 90 and for $1 \mathrm{e}$ it is 270 seconds. From the spectra, conversion to the $Z$ isomer is estimated to be about $40-50 \%$ under $366 \mathrm{~nm}$ light photostationary state.

In addition to UV-visible absorption spectroscopy measurements, the reversible conformation changes of 95 azobenzene monolayer surface were confirmed by means of contact angle measurements (Fig. 2). The contact angle of monolayer surface of $1 \mathrm{a}$ before irradiation was $65 \pm 1^{\circ}$. After UV irradiation it increased to $69 \pm 1^{\circ}$. Regardless of the terminal group, the contact angle was increased after irradiation with $366 \mathrm{~nm}$ 100 light irradiation. Monolayers of $\mathbf{1 b}-\mathbf{e}$ also showed good reversible photo switching of surface wettability by UV and visible irradiation (data not shown).

The velocity of rhodamine-labelled MTs on kinesin-containing surface, functionalized with azobenzene derivatives was 105 evaluated with the inverted motility assay. ${ }^{11}$ It is already known that in order to get the proper orientation and to avoid inactivation of kinesin, blocking proteins such as casein, streptavidin, bovine serum albumin are adsorbed first on the substrate. ${ }^{48-51}$ But in the present study we systematically removed 

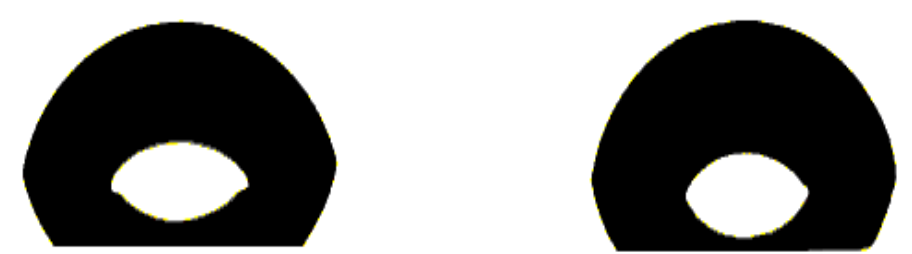

Fig. 2 Reversible switching of contact angle of photoresponsive compound of 1a for water before irradiation (left) and after $366 \mathrm{~nm}$ light irradiation (right).

(1)

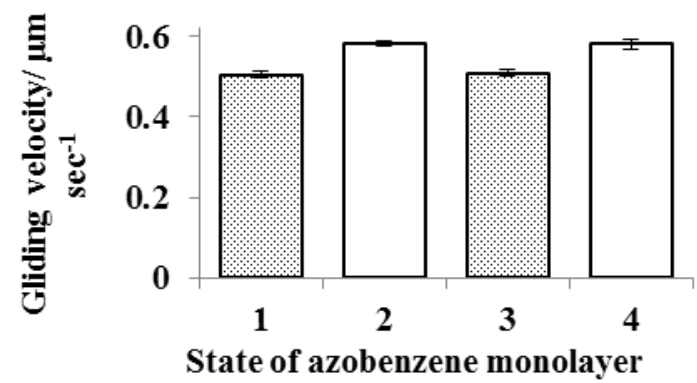

(3)

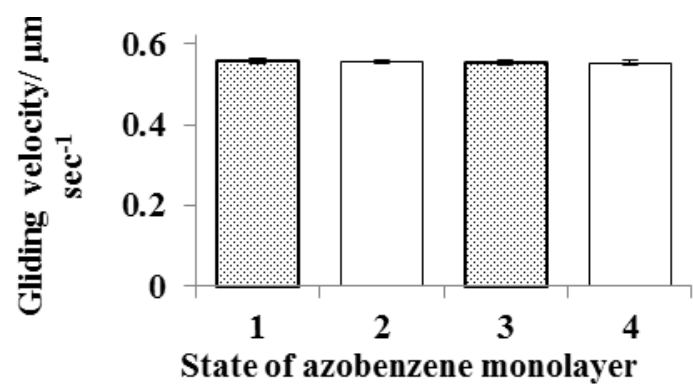

(2)

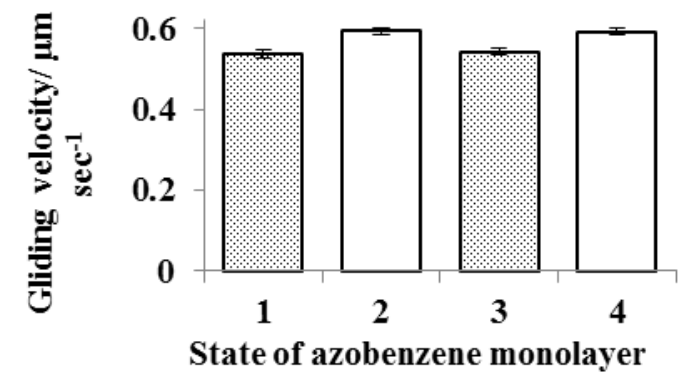

(4)

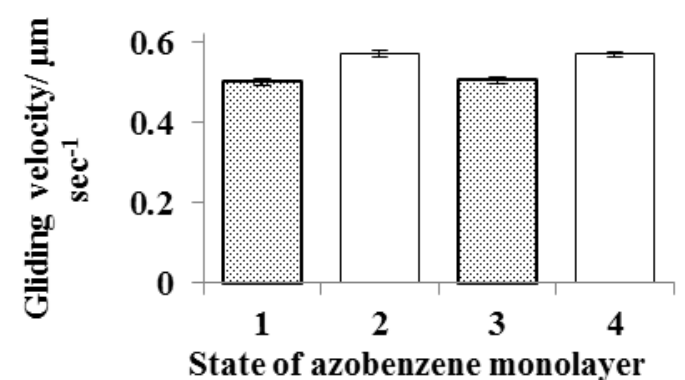

Fig. 3 Fast and slow mode of microtubule motility upon photoirradiation. (1): 1b, (2): 1c, (3): 1d, (4): 1e. State 1: Prior to irradiation. State 2: After irradiation at $366 \mathrm{~nm}$. State 3: After subsequent irradiation at visible light. State 4: After subsequent irradiation at $366 \mathrm{~nm}$. The number of microtubules 10 measured was $38,44,35$, and 30 for $\mathbf{1 b} ; 40,35,37$, and 25 for $\mathbf{1 c} ; 32,32,30$, and 25 for $\mathbf{1 d}$; and 46, 41, 43, and 37 for $\mathbf{1 e}$; for states $1-4$, respectively. The error bars indicate the standard error of the mean. 


\section{Cite this: DOI: 10.1039/c0xx00000x}

\section{www.rsc.org/xxxxxx}

(1)

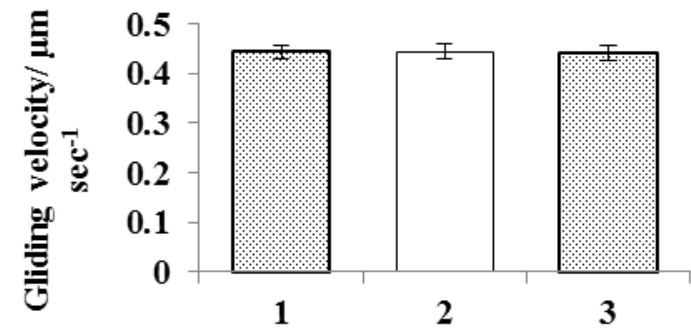

State of azobenzene monolayer

(3)

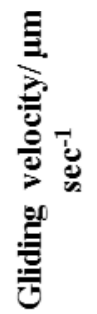

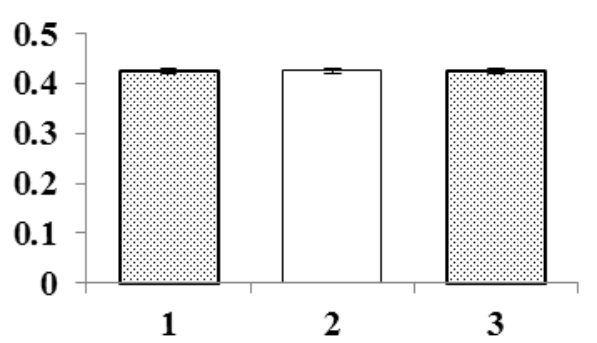

State of azobenzene monolayer
(2)

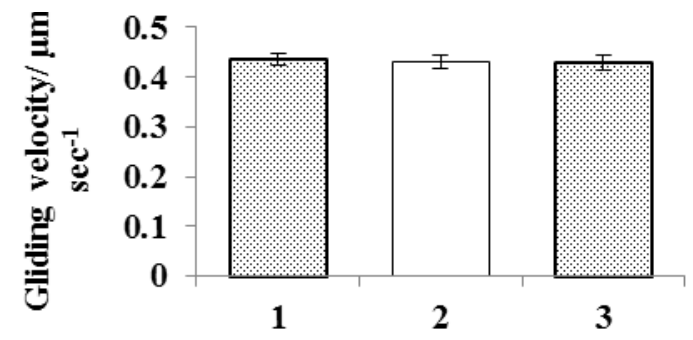

State of azobenzene monolayer

(4)

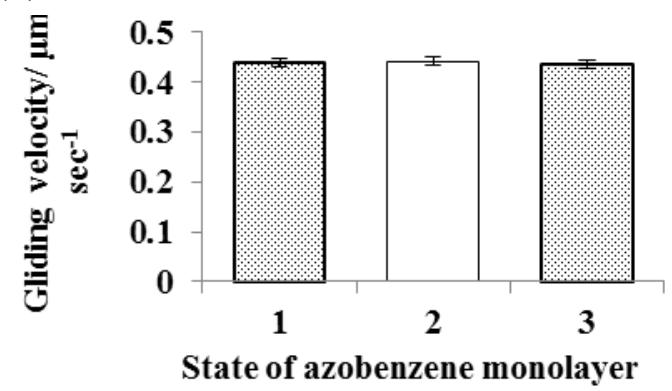

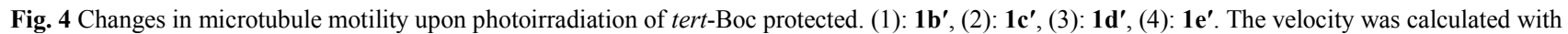
the shortest distance of the terminal positions of the microtubule before and after 10 seconds motility. State 1: Prior to irradiation. State 2: After irradiation at $366 \mathrm{~nm}$. State 3: After subsequent irradiation at visible light. The error bars indicate the standard error of the mean.

the blocking proteins and introduced kinesin directly on the photoresponsive azobenzene monolayer. Since there is no blocking protein, we first confirmed the kinesin activity with observable microtubule speed by measuring the average speed of 10 a large population of microtubules. We found that, even though the length of time that the kinesin was catalytically active on the azobenzene monolayers was shorter than that on the corresponding surfaces having blocking proteins, it was sufficiently long enough to perform all of the motility 15 experiments prior to a serious decrease in activity. Next, we investigated the effect of UV light irradiation on the motility of MTs driven by kinesin in the presence of ATP without functionalized surface. The result shows that the gliding velocities of MTs with (black circle) and without (triangle) UV 20 irradiation was almost identical (ESI Fig. S2). This suggested that, UV irradiation on a flow cell did not make any detectable effect on the microtubule gliding motility.

In order to know the effect of isomerization of the azobenzene moieties for the motility of rhodamine-labelled microtubules 25 driven by the kinesin-mediated ATP hydrolysis, starting with the azobenzene monolayer in the $E$ state, the average gliding velocity of the microtubules was measured. The $Z$ rich state of the azobenzene monolayer obtained after $366 \mathrm{~nm}$ wavelength light irradiation of flow cell, showed the higher velocity of the 30 microtubule than in the $E$ state in 1a-c and 1e, making it possible to induce the statistically significant velocity change. Further irradiation of flow cell with appropriate visible light, the motility of microtubule was reached to its almost initial state and the velocity increased again upon further irradiation with $366 \mathrm{~nm}$ 35 wavelength of light. In contrast, upon alternate irradiation of flow cell of 1d with UV and visible light, no change was observed in the motility of microtubule. Fig. 3 shows variable and reversible microtubule speeds observed in the gliding assay in four states: prior to irradiation $(100 \% E)$, after irradiation at $366 \mathrm{~nm}$ (Z-rich), 40 after subsequent irradiation with visible light ( $E$-rich) and after subsequent irradiation at $366 \mathrm{~nm}$ (Z-rich).

Video in ESI shows microtubules motility of $\mathbf{1 a}$ before and after $366 \mathrm{~nm}$ irradiation. Starting with the flow cell in its $E$ isomer rich state and the subsequent irradiation with $366 \mathrm{~nm}$ 45 wavelength light, the controllable changes in the velocity of $\mathbf{1 a}$, 1b and 1e was $13 \sim 15 \%$ of the initial velocity in the $E$ form. In the case of $1 \mathrm{c}$ with a glutamic acid residue the speed difference between the $E$ and $Z$ rich state was found to be about $9 \%$. At the same time 1d with a malonic acid substituent shows the identical 50 microtubule velocity in $E$ and $Z$ isomeric forms. In contrast to the results of photo-regulation of motility with the deprotected amino acid substituted moieties; no change in the velocity of the microtubules upon photoirradiation was detected (Fig. 4).

In our previous report ${ }^{28}$ two possible mechanisms were 55 suggested to explain the change in the motility of kinesinmicrotubule system upon the photoisomerization of azobenzene monolayer surface. One is that the photoisomerization induced a change in the interaction between the monolayer surface having positively charged amino groups and microtubules being rich in 
(1)

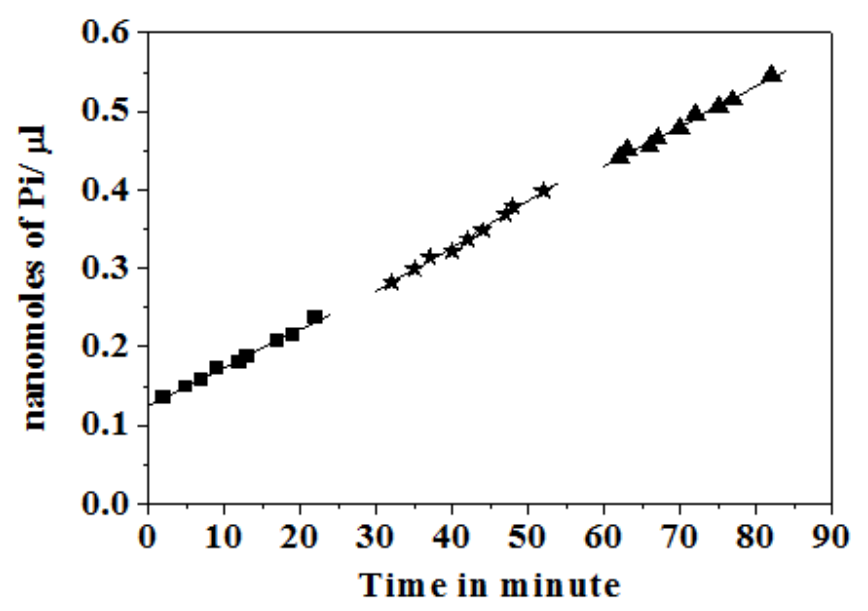

(2)

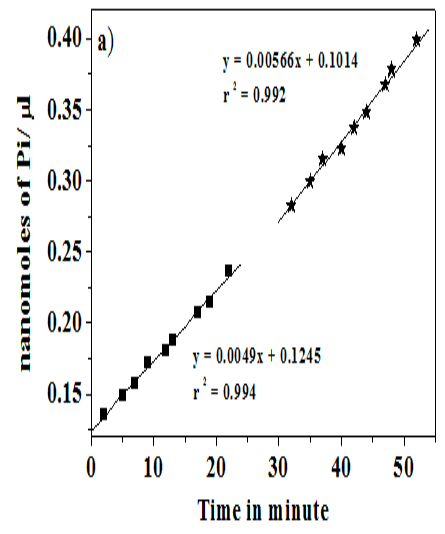

(3)

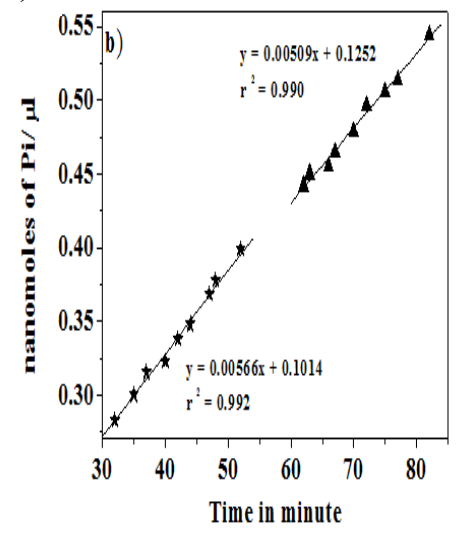

Fig. 5 Time dependent inorganic phosphate releases from hydrolysis of ATP by kinesin at different environments of azobenzene functionalized surface of 1a before irradiation [(1) squares], after $366 \mathrm{~nm}$ irradiation [(1) stars] and after visible light irradiation [(1) triangles]. Enlarged figure of phosphate release 5 before and after $366 \mathrm{~nm}$ irradiation (2) and after $366 \mathrm{~nm}$ and $>500 \mathrm{~nm}$ irradiation (3).

the negatively charged carboxylate groups. ${ }^{52}$ The other one is that the photoresponsive monolayer affects to the activity of kinesin.

To investigate the influence of azobenzene functionalized monolayer on the activity of kinesin, a microtubule activated

10 ATPase assay was performed in the same buffer condition as the motility assay. We determined the rate at which ATP hydrolysis products are formed by using malachite green colorimetric method as explained in the experimental section. Fig. 5 shows the time dependent inorganic phosphate release from hydrolysis of 15 ATP by kinesin at different states of 1a. When the azobenzene moiety of 1a was in $E$ form, the initial steady state phosphate release rate was $5.05 \times 10^{-3} \mathrm{nmol} \mathrm{min}^{-1} \mu \mathrm{l}^{-1}$. Upon UV irradiation of flow cell with $366 \mathrm{~nm}$ light about 30 seconds, phosphate release rate was found to be increased to $5.74 \times 10^{-3} \mathrm{nmol} \mathrm{min}^{-1} \mu \mathrm{l}^{-}$ ${ }_{20}{ }^{1}$. The difference in the release rates of phosphate ion between $E$ and $Z$ isomer was $14 \%$ which shows the comparable correlation with the gliding velocity of MT at two different isomeric surfaces. On further irradiation with $>500 \mathrm{~nm}$, the inorganic phosphate release rate reduced to $5.14 \times 10^{-3} \mathrm{nmol} \min ^{-1} \mu \mathrm{l}^{-1}$ and the 25 difference in the release rates between $E$ and $Z$ isomer was $12 \%$. Similarly, the rate of inorganic phosphate release was switched for 1b-c and 1e monolayer surfaces, with similar behaviour as seen in the gliding velocity of MT at two different isomeric surfaces (ESI Fig. S3-S6). In contrast, the release rate of 30 inorganic phosphate in protected azobenzene derivatives upon alternate irradiation with UV and visible light is the same, a striking exact correlation with the MT speeds on the two, $E$ and $Z$, isomeric states (data not shown).

From the results it is clear that, the change in motility of 35 microtubule depends on terminal group of the surface monolayer. 
When our photoresponsive azobenzene monolayer $\mathbf{1 a}, \mathbf{1 b}$ or $\mathbf{1 e}$ presenting two or more free amino groups having a net positive charge in the buffer solution was used for the inverted motility assay experiment, the gliding velocity of microtubule in the $Z$ 5 state was $13 \sim 15 \%$ higher than the gliding velocity in the $E$ state. The azobenzene monolayer surface of $\mathbf{1 c}$ offering one negatively charged carboxyl group and one positively charged amino group gave an increase in microtubule velocity of $9 \%$ in the $Z$ state than the gliding velocity in the $E$ state. In contrast negatively 10 charged surface of 1d and non-polar surface of protected monolayer didn't show any change in the gliding velocity between two isomeric forms.

The striking exact correlation between the difference in the gliding velocity of microtubule driven by kinesin and the 15 difference in the rate at which the ATP hydrolysis products formed at two isomeric surfaces, $E$ and $Z$, allows us to conclude that, the change in the microtubule gliding motility is mainly due to the change in activity of kinesin. It is already reported that the activity or the reaction kinetics of kinesin is changed depending 20 on the nature of the surface of the substrate and in some extreme cases, the kinesin is completely inactivated in the absence of a blocking protein on some substrates. ${ }^{50}$ Recently Martin et al. reported that when the polymer of hydroxymethylated derivative of EDOT, (2,3-dihydrothieno [3,4-b][1,4]dioxin-methanol, ${ }_{25}$ ' $\mathrm{CH}_{2} \mathrm{OH}$-EDOT') on surface was electrochemically transformed from a cationic (doped) state to a neutral (dedoped) state and vice versa, the ATPase activity of the adsorbed kinesin can be controlled reversibly, resulted in the reversible control of the gliding speed of the associated microtubule between fast (in 30 dedoped state) and slow (in doped state) mode. ${ }^{53}$ It is reasonably expected that the terminal amino groups with positive charge dive into the forest of alkyl chain of 2a or 2b during $E$-to- $Z$ photoisomerization upon $366 \mathrm{~nm}$ wavelength light irradiation, which is proved by the increase in contact angle of the monolayer.

35 So when the positively charged amino groups are exposed to the surface at $E$ state, the slowdown of microtubule motility is observed and when the alkyl chain is exposed to the surface at $Z$ state, the motility of microtubule increased.

The relationship between the kinesin activity and the presence 40 of positive charges on the surface is not clear. The possible mechanism which can explain the change in the kinesin activity and the gliding motility of the microtubule is that the positive charge might have affected the secondary structure of the kinesin, resulting in a change in its activity of ATP hydrolysis.

\section{${ }_{45}$ Conclusions}

We observed that an azobenzene monolayer surface needs to have free amino terminal groups for the dynamic control of the motility of microtubule. The surface of azobenzene monolayer with terminal amino groups can dynamically control the ATP ${ }_{50}$ hydrolysis activity of kinesin which further induces the change in motility of microtubule. We believe that the reported method could facilitate the rational design of new type of photo controllable molecular devices if we could control the motility of microtubule between complete ON/ OFF switching. Currently we

55 are trying to find out the more suitable terminal group which can control completely the ON/ OFF switching of the function of kinesin.

\section{Acknowledgments}

This work was supported by a grant-in-aid for science research in 60 a priority area "New Frontiers in Photochromism (no. 471)" from the Ministry of Education, Culture, Sports, Science, and Technology (MEXT), Japan. M.K.A.R. acknowledges The Ushio Foundation for a scholarship. We thanks to Dr. Y. Hiratsuka, Dr. Y. Hachikubo and Dr. T. Q. P. Uyeda for kindly giving ${ }_{65}$ recombinant kinesin construct and Dr. A. Kakugo, Y. Tamura and Prof. J. P. Gong for help in purification of protein specimen.

\section{Notes and references}

${ }^{a}$ Research Institute for Electronic Science, Hokkaido University, N20 W10, Kita-ku, 001-0020,Sapporo, Hokkaido, Japan. Fax: +81 11706 70 9357.Tel: +81 11706 9356.E-mail:tamaoki@es.hokudai.ac.jp.

$\uparrow$ Electronic Supplementary Information (ESI) available: [details of any supplementary information available should be included here]. See DOI: $10.1039 / \mathrm{b} 000000 \mathrm{x} /$

t Footnotes should appear here. These might include comments relevant 75 to but not central to the matter under discussion, limited experimental and spectral data, and crystallographic data.

1 A. Agarwal and H. Hess, Prog. Polym. Sci., 2010, 35, 252-277.

2 A. Goel and V. Vogel, Nat. Nanotechnol., 2008, 3, 465-475.

3 M. G. L van den Heuvel and C. Dekker, Science, 2007, 317, 333-336.

804 T. Fischer and H. Hess, J. Mater. Chem., 2007, 17, 943-951.

5 J. R. Dennis, J. Howard and V. Vogel, Nanotechnology, 1999, 10, 232 236.

6 M. G. L. van den Heuvel, M. P. De Graaff and C. Dekker, Science, 2006, 312, 910-914.

857 L. Ionov, M. Stamm and S. Diez, Nano Lett., 2005, 5, 1910-1914.

8 K. J. Bohm, J. Beeg, G. M. zu Horste, R. Stracke and E. Unger, IEEE Trans. Adv. Packaging, 2005, 28, 571-576.

9 R. K. Doot, H. Hess and V. Vogel, Soft Matter, 2007, 3, 349-356.

10 R. D Vale, T. S. Reese and M. P. Sheetz, Cell, 1985, 42, 39-50.

9011 J. Howard, A. J. Hudspeth and R. D. Vale, Nature, 1989, 342, 154-158.

12 B. J. Schnapp, T. S. Reese and R. Bechtold, J. Cell Biol., 1992, 119, 389-399.

13 S. T. Brady, Nature, 1985, 317, 73-75.

14 R. D. Vale, T. S. Reese and M. P. Sheetz, Cell, 1985, 42, 39-50.

9515 N. Hirokawa, Y. Noda and Y. Okada, Curr. Opin. Cell Biol., 1998, 10, 60-73.

16 N. Hirokawa and R. Takemura, Nat. Rev. Neurosci., 2005, 6, 201-214.

17 R. D. Vale, Cell, 2003, 112, 467-480.

18 D. L. Coy, M. Wagenbach and J. Howard, J. J. Biol. Chem., 1999, 274, 3667-3671.

19 S. M. Block, L. S. Goldstein and B. J. Schnapp, Nature, 1990, 348, 348-352.

20 W. O. Hancock and J. Howard, J. Cell biol., 1998, 140, 1395-1405.

21 Y. Hiratsuka, T. Tada, K. Oiwa, T. Kanayama and T. Q. P. Uyeda, Biophys. J., 2001, 81, 1555-1561.

22 M. G. L. van denHeuvel, C. T. Butcher, R. M. M. Smeets, S. Diez and C. Dekker, Nano Lett., 2005, 5, 1117-1122.

23 M. Platt, G. Muthukrishnan, W. O. Hancock and M. E. Williams, $J$ Am. Chem. Soc., 2005, 127, 15686-15687.

11024 L. Limberis, J. J. Magda and R. J. Stewart, Nano Lett., 2001, 1, 277 280

25 H. Higuchi, E. Muto, Y. Inoue and T. Yanagida, Proc. Natl. Acad. Sci. U.S.A., 1997, 94, 4395-4400.

26 H. Hess, J. Clemmens, D. Qin, J. Howard and V. Vogel, Nano Lett., 2001, 1, 235-239.

27 A. Nomura, T. Q. P. Uyeda, N. Yumoto and Y. Tatsu, Chem. Commun., 2006, 3588-3590.

28 M. K. A. Rahim, T. Fukaminato, T. Kamei and N. Tamaoki, Langmuir, 2011, 27, 10347-10350.

2029 F. Ercole, T. P. Davis and R. A. Evans, Polym. Chem., 2010, 1, 37-54.

30 N. Tamaoki, and T. Kamei, J. Photochem. Photobiol. C., 2010, 11, 4761.

31 T. Seki and S. Nagano, Chem. Lett., 2008, 37, 484-489. 
32 S. Yagai and A. Kitamura, Chem. Soc. Rev., 2008, 37, 1520-1529.

33 K. G. Yager and C. J. Barrett, J. Photochem. Photobiol. A., 2006, 182, 250-261.

34 C. J. Barrett, J. Mamiya, K. G. Yager and T. Ikeda. Soft Matter, 2007, 3, 1249-1261.

35 The following article describes the photocontrol of the ATPase activity of kinesin but not the motility using an azobenzene derivative: M. D. Yamada, Y. Nakajima, H. Maeda and S. Maruta, J. Biochem., 2007, 142, 691-698.

1036 P. Santurri, F. Robbins and R. Stubbings, Organic Syntheses, 1973, Coll. Vol. 5, 341; 1960, 40, 18.

37 F. Cisnetti, R. Ballardini, A. Credi, M. T. Gandolfi, S. Masiero, F. Negri, S. Pieraccini and G. P. Spada, Chem. Eur. J., 2004, 10, 2011 2021.

1538 K. Aoki, T. Seki, Y. Suzuki, T. Tamaki, A. Hosoki and K. Ichimura, Langmuir, 1992, 8, 1007-1013.

39 M. Dasog, A. Kavianpour, M. F. Paige, H. B. Kraatz and R. W. J. Scott, Can. J. Chem., 2008, 86, 368-375.

40 M. Castoldi and A. V. Popov, Protein Expression and Purification, 2003, 32, 83-88.

41 H. Suzuki, K. Oiwa, A. Yamada, H. Sakakibara, H. Nakayama and S. Mashiko, Jpn. J. Appl. Phys., 1995, 34, 3937-3941.

42 J. Howard, A. J. Hunt and S. Baek, Methods in Cell Biology, 1993, 39,137-147.

25 43T. Kodama, K. Fukui and K. Kometani, J. Biochem., 1986, 99, 14651472 .

44 H. H. Hess and J. E. Derr, Anal. Biochem., 1975,63, 607-613.

45 G. Pace, V. Ferri, C. Grave, M. Elbing, C. von Hanisch, M. Zharnikov, M. Mayor, M. A. Rampi and P. Samori, Proc. Natl. Acad. Sci. U.S.A., 2007, 104, 9937-9942.

46 K. G. Yager and C. J. Barrett, J. Photochem. Photobiol. A., 2006, 182, 250-261.

47 K. Ichimura, Y. Suzuki, T. Seki, A. Hosoki and K. Aoki, Langmuir, 1988, 4, 1214-1216.

3548 T. Ozeki, V. Verma, M. Uppalapati, M.; Y. Suzuki, M. Nakamura, J. M. Catchmark and W. O. Hancock, Biophys. J., 2009, 96, 3305-3318.

49 D. J. G. Bakewell and D. V. Nicolau, Aust. J. Chem., 2007, 60, 314 332.

50 C. Brunner, K. H. Ernst, H. Hess and V. Vogel, Nanotechnology, 2004, 15, S540-S548

51 E. Berliner, H. K. Mahtani, S. Karki, L. F. Chu, J. E. Cronan and J. Gelles, J. Biol. Chem., 1994, 269, 8610-8615.

52 D. C. Turner, C. Chang, K. Fang, S. L. Brandow and D. B. Murphy, Biophys. J., 1995, 69, 2782-2789.

4553 B. D. Martin, L. M. Velea, C. M. Soto, C. M. Whitaker, B. P .Gaber and B. Ratna, Nanotechnology, 2007, 18, 055103. 